Vol: 2, Issue: 11

November/2021

DOI: http://dx.doi.org/10.47742/ijbssr.v2n11p1

https://ijbssrnet.com/index.php/ijbssr

\title{
Pre-Trial in the Criminal Justice System in Military Criminal Judges in Indonesia
}

\author{
Sugeng Sutrisno* \\ Faculty of Law \\ Universitas Krisnadwipayana \\ Campus Unkris PO BOX 7774/Jat CM Jakarta 13077, Indonesia \\ Email: sugengsutrisno77@gmail.com
}

Indonesia

\section{A R T I C L E I N F O \\ Article history: \\ Received: $\quad 02$ Nov 2021 \\ Revised: $\quad 15$ Nov 2021 \\ Accepted: $\quad 25$ Nov 2021 \\ Publication: 30 Nov 2021 \\ DOI: $10.47742 /$ ijbssr.v2n11p1}

https://creativecommons.org/licenses/by/4.0/

\section{A B S T R A C T}

Law enforcement in the Military Court System in the settlement of criminal cases committed by TNI soldiers is seen as not yet fully guaranteeing legal protection for the rights of suspects, this is due to the absence of a control agency that oversees the actions of law enforcement officers in carrying out their duties and authorities as is the case in the system. General Court. This condition should not drag on indefinitely, because it will affect the law enforcement process and harm the suspect to fight for his rights to obtain justice which results in human rights violations (TNI soldiers).

The purpose of the establishment of the Pretrial Institution is as stated in the Elucidation of Article 80 of the Criminal Procedure Code which states that this article intends to uphold law, justice, and truth through horizontal supervision.

Settlement of criminal cases in Indonesia in addition to the Code of Criminal Procedure Code (KUHAP) which applies to civil society, we also recognize the existence of the Military Criminal Procedure Code which is regulated in Law Number 31 of 1997 concerning Military Courts, namely the law that regulates the procedure for resolving criminal cases. a criminal case committed by a TNI soldier. The Law on Military Courts includes the provisions of the litigation process (Military Criminal Procedure Law) starting from the investigation stage, submission of cases, the examination process at trial to the implementation of decisions. 31 of 1997 does not regulate pretrial. In several cases in the Military Court where a suspect was detained without a warrant for detention or was late in obtaining a warrant for detention, therefore such actions may conflict with the principles applicable in the provisions of criminal law so that they do not respect the position of the suspect as a creature created by God, even the act can lead to human rights violators. Therefore, in the military justice system in Indonesia, pretrial institutions are needed as a form of horizontal external supervision.

Keywords: Pretrial, Military Criminal System, Indonesia.

\section{INTRODUCTION}

Indonesia as a state of law should provide legal guarantees to every citizen, and every Indonesian citizen is required to support the creation of a fair law enforcement and implementation process, because the enforcement and implementation of the law is the ideal of the entire Indonesian nation, as stated in the Preamble The 1945 Constitution of the Republic of Indonesia in the Fourth Paragraph which states: Then from that to form an Indonesian state government that protects the entire Indonesian nation and the entire homeland of Indonesia and to promote public welfare, educate the nation's life, and participates in carrying out world order based on independence, eternal peace and social justice (Nasution, 2014).

The process of law enforcement must be under Pancasila and the 1945 Constitution of the Republic of Indonesia (UUD 1945) which is the source of all sources of law in Indonesia. One of the important principles that must be owned by a state of the law is the guarantee of the implementation of the powers of an independent judiciary, free from any interference from extrajudicial powers (Mertokusumo, 2005) (outside the court/judicial power) to administer justice to uphold order, justice, truth, and legal certainty that can provide protection and a sense of security to the community (Mujahidin, 2007).

The criminal justice system in Indonesia is largely regulated in Law Number 8 of 1981 concerning the Criminal Procedure Code (KUHAP). This law serves to limit the power of the state is acting against citizens who are involved in the criminal justice process and is tasked with implementing the material criminal law contained in Law Number 1 of 1946 concerning the Criminal Code (KUHP).

The pretrial institution was born simultaneously with the enactment of the Criminal Procedure Code by adopting several principles in the habeas corpus act in the judicial system that applies to the justice system in Anglo Saxon countries. The Habeas corpus act is a statute carried out by King Charles in 1679. Where the statute was amended in parliament which allowed a person to maintain his position and provided fundamental guarantees for human rights, especially the right to independence. This habeas corpus act warrant is issued by the court to the party who is in custody (police or prosecutor) through a simple, direct and open procedure so that it can be used by anyone 


\title{
International Journal of Business and Social Science Research
}

\author{
Vol: 2, Issue: 11 \\ November $/ 2021$ \\ DOI: http://dx.doi.org/10.47742/ijbssr.v2n11p1 \\ https://ijbssrnet.com/index.php/ijbssr
}

Prior to the enactment of the Criminal Procedure Code, the implementation of criminal law enforcement was carried out according to HIR (Het Herziene Inlandsh Reglement) Staadblad 1941 Number 44, and RBg (Rechtreglement voor de Buitengewesten) Staadblad 1927 Number 227. Article 1 Transitional Rules of the 1945 Constitution, however, because the 2 (two) laws were made during the colonial period, so they do not yet contain the concept of protecting Human Rights (Human Rights) for the Suspect/Defendant. HIR and RBg do not explicitly determine the limitation on the authority of officials conducting examinations in carrying out coercive measures such as arrest, detention, search, confiscation for investigation, or prosecution (Witanto, 2019).

In principle, the rule of law is required to have a criminal procedural law system that reflects Indonesia's national policy by providing arrangements regarding the rights and obligations of parties involved in the criminal law enforcement process, both for suspects and law enforcement officers at each examination so that on December 31 In 1981, the Criminal Procedure Code (KUHAP) was officially promulgated.

The pretrial institution was born simultaneously with the enactment of the Criminal Procedure Code by adopting several principles in the habeas corpus act in the judicial system that applies to the justice system in Anglo Saxon countries. The Habeas corpus act is a statute carried out by King Charles in 1679. Where the statute was amended in parliament which allowed a person to maintain his position and provided fundamental guarantees for human rights, especially the right to independence. This habeas corpus act warrant is issued by the court to the party who is in custody (police or prosecutor) through a simple, direct and open procedure so that it can be used by anyone (Witanto, 2019)

The Habeas corpus act gives a person the right to sue the official who has detained him to prove that the detention is under the applicable legal provisions. The Habeas corpus act is made as a control agent against the authority of law enforcement officials equipped with the authority to make arrests and detentions so that the authorized officials act cautiously and do not abuse their authority to win and detain someone without proper procedures. The concept then inspired the founders of the Criminal Procedure Code to include a horizontal control agency over the authority of investigators and public prosecutors in carrying out their duties (Chaerul, 2021).

In Article 1 point 10 of the Criminal Procedure Code which is emphasized by Article 77 of the Criminal Procedure Code, it is explained that the District Court has the authority to examine and decide whether or not an arrest, detention, termination of the investigation, or termination of prosecution as well as compensation and/or rehabilitation for a person whose criminal case is terminated at the investigation level or prosecution. These provisions are needed for the supervision of law enforcement officers so that in carrying out their authority they do not commit fraud or abuse of authority.

In the application of coercive measures (dwang midelen), as is possible in the criminal justice process such as arrests and detentions, even the determination as a suspect, does not demean human dignity, it is permissible for a new institution to carry out supervision, namely the Pretrial Institution. So it is clear that the Pretrial Institution is intended to supervise coercive measures by functional law enforcement officers, in this case, investigators and public prosecutors. This Pretrial Institution is intended as the authority of the court before examining the subject matter of the case. Why is that, because everyone who is suspected, arrested detained, and/or prosecuted before a court hearing, must be presumed innocent until a court decision declares his guilt and obtains permanent legal force, as is the essence of the principle of Presumption of Innocence. Likewise, for losses caused by wrongful arrests (error in persona), the suspect, his attorney or his family can apply for compensation and rehabilitation (Pangaribuan, 2012).

In the settlement of criminal cases in Indonesia, apart from the Criminal Procedure Code which applies to civil society, there is also a Military Criminal Procedure Code which is regulated in Law Number 31 of 1997 concerning Military Courts, namely the law that regulates procedures for resolving criminal cases committed by a TNI soldier. The Law on Military Courts includes the provisions of the litigation process (Military Criminal Procedure Code) starting from the investigation stage, submission of cases, the examination process at trial to the implementation of decisions. However, in its development, the Military Criminal Procedure Code is felt to be incomplete because there are still rights of the Suspect / Accused soldier or military which have not been accommodated when he is carried out arbitrarily by Law Enforcement Officials in his examination. This is different from the Criminal Procedure Code which is used for a civil society where there is the protection of the human rights of civilians (suspects) in the arbitrary actions of law enforcement officials, namely the existence of a pretrial institution.

The existence of a Pretrial Institution in the Criminal Procedure Code as described above is not regulated in Law of the Republic of Indonesia Number 31 of 1997 concerning Military Courts, to ensure the protection of human rights for suspected TNI soldiers and guarantees that law enforcement officials carry out their duties under the laws and regulations. Invitation in the Military Justice system does not exist. This, of course, creates discrimination and injustice for members of the military or TNI soldiers who are also Indonesian citizens (Widagdo, 2012).

The legal vacuum as happened in the military court environment will have juridical and sociological implications for TNI soldiers because, for the military who are harmed by the negligence of the unit leadership, there is no access to obtain rights that should be pursued through the Pretrial route if there are soldiers who feel that their rights have been harmed.

The void in law enforcement at the lowest level as a result of the absence of a pretrial institution in the criminal justice system in the military justice environment has created uncertainty and justice for justice seekers, especially TNI soldiers who were harmed due to detentions that were not or were late in issuing detention warrants from authorized officials. In this case, the superior has the right to punish (Ankum) and the officer submitting the case (Papera) (Article 1 paragraph (9) of Law Number 31 of 1997 concerning Military Courts). 


\title{
International Journal of Business and Social Science Research
}

\author{
Vol: 2, Issue: 11 \\ November $/ 2021$ \\ DOI: http://dx.doi.org/10.47742/ijbssr.v2n11p1 \\ https://ijbssrnet.com/index.php/ijbssr
}

The criminal justice system within the military court environment. Ankum's authority as commander as investigator includes, among others, conducting examinations, detentions, searches, and confiscations under the Unity of Command Principle. The authority to investigate and investigate criminal acts carried out by subordinate soldiers is the inherent authority of the Commander as Ankum which in its implementation is delegated to the Military Police and/or Military Prosecutor, distinguishes from the General Court Environment that these powers are attached to the investigators of the Police or the Prosecutor's Office.

The development of the military situation and conditions is so rapid that it demands an extra role from the Commanders to carry out their fairly solid official duties, resulting in the commander's role being prioritized over his role as law enforcement, this often results in errors or mistakes in the legal process carried out. The commanders do not seem to care about the fate of their members who are in detention. Whereas the urgency of Ankum in Military Courts departs from the principle of 'unity of command' and the commander is responsible. This, of course, violates the principle of One Unity of Command and Responsible Commander which is the basis for the establishment of the Military Court.

The problem of law enforcement in the Military Courts environment in providing rights for justice seekers especially suspects or defendants in the context of realizing equal rights for every citizen before the law and to guarantee the injustice of law enforcers in the Military Courts is interesting for the author to research it. For this reason, the author considers it very necessary to contribute thoughts to the development of law in Indonesia, especially in the Military Courts environment through this research for the following reasons: First, to the best of the author's knowledge, this topic has never been researched either in the military or civilian circles, even in the form of scientific writings/works. Second, until now members of the military or TNI soldiers who have become suspects have often lost their rights because they cannot take legal action to file an objection to detention which is considered to violate the applicable criminal law procedures.

Third, to answer the pros and cons regarding the existence of Pretrial, only opinions or opinions in the Military Environment have surfaced, but no one has written or conducted a more indepth study. The pros and cons developed again in the specifics and peculiarities/characteristics of Military Courts were from the beginning of its formation, that the military has its characteristics that are different from ordinary civilians because the Law on Military Courts departs from the Unity of Command Principle, the Principle of Commanders. Fourth, to provide input and new legal concepts to the criminal justice system in Indonesia, particularly the Military Courts, so that they are in line with other courts under the Supreme Court.

\section{FORMULATION OF THE PROBLEM}

Based on the above background, several formulations of the problem can be proposed as follows:

1. Why is Pretrial Institution needed in the Military Justice System in Indonesia?
2. What is the conception of the Pretrial Institution in the criminal justice system within the Military Courts?

3. What are the implications/influence of the establishment of a Pretrial Institution in the criminal justice system within the TNI?

\section{RESEARCH METHODS}

\section{Types of Research and Approach}

The research method in this writing, author uses normative juridical research, according to Soetandyo Wignjosoebroto normative legal research is legal research that focuses on the study or study of legislation in a coherent legal system. In this study, the authors conducted a study and analysis of whether a pretrial institution is needed in the Military Justice System in Indonesia, which has not been regulated in the Republic of Indonesia Law Number 31 of 1997 concerning Military Courts, which is the Military Court Procedural Law (Wignjosoebroto, 1995). In this study, the researchers used four approaches (approach), namely: the statute approach, the philosophical approach, the conceptual approach, the criminal law policy approach, and the futuristic approach.

\section{a. Legislative Approach}

This writing is a type of normative research, so the author uses a statutory approach because what will be studied are various legal rules that focus on as well as the central theme of a study. The approach to legislation is used by the author to research and analyze the laws and regulations that regulate the Pretrial Institution. In this case, a statutory approach is used to research and analyze the need for a Pretrial Institution in the Military Justice System in Indonesia, which has not been regulated in the Law of the Republic of Indonesia Number 31 of 1997 concerning Military Courts, which is the Procedural Law of Military Courts.

b. Philosophical Approach

The philosophical approach is carried out to seek or find the logical ratio and ontological basis of the birth of law so that the philosophical content underlying the making of law can be captured. This approach is carried out within the framework of understanding the philosophy of the rule of law from time to time, as well as understanding the changes and developments in the philosophy that underlies the rule of law. This approach is carried out by examining the background and development of regulations regarding the legal issues faced. In this case, the Law of the Republic of Indonesia Number 31 of 1997 concerning Military Courts, what is the background behind the birth of the law and why does the law not regulate the Pretrial Institution.

c. The sociological or empirical juridical approach is used to examine facts in the field, both juridical and nonjuridical facts to find reasons for the existence of Pretrial in the Military Justice System in Indonesia.

d. Conceptual Approach

This approach departs from the views and doctrines that develop in the science of law. This approach is important 


\author{
Vol: 2, Issue: 11 \\ November/2021 \\ DOI: http://dx.doi.org/10.47742/ijbssr.v2n11p1 \\ https://ijbssrnet.com/index.php/ijbssr
}

because an understanding of the views/doctrines that develop in legal science can be a basis for building legal arguments when solving legal issues at hand. The views/doctrine will clarify ideas by providing legal understandings, legal concepts, and legal principles that are relevant to the problem. The conceptual approach is used in this study to examine and analyze what is meant by pretrial institutions and the relationship between human rights and pretrial institutions in the military justice system in Indonesia.

e. Criminal Law Policy Approach

Criminal law policy or politics is a policy line to determine how far the applicable criminal provisions need to be changed or updated, meaning that it concerns the urgency of criminal law reform, then to determine what can be done to prevent the occurrence of criminal acts, meaning that it involves efforts to prevent criminal acts as well as to determine how the investigation, prosecution, trial and execution of criminal offenses must be carried out, meaning that it is related to efforts to overcome crime through the criminal justice system.

\section{Source of Legal Material}

In this legal research, the materials used are primary, secondary, and tertiary legal materials.

\section{a. Primary Legal Material}

Primary legal materials are legal materials that are binding and consist of basic norms or basic rules, namely the Preamble to the 1945 Constitution, basic regulations, laws and regulations, uncodified legal materials, jurisprudence, and treaties. The primary legal material in this writing is Article 27 of the 1945 Constitution and Law of the Republic of Indonesia Number 39 of 1999 concerning Human Rights. The regulation of the protection of human rights in the area/context of law enforcement is affirmed in Article $28 \mathrm{D}$ paragraph (1) of the 1945 Constitution "everyone has the right to recognition, guarantees, protection, and legal certainty that is fair and equal treatment before the law." Likewise, it is also clearly stated in Article 34 of Law Number 39 of 1999 concerning Human Rights, namely "everyone may not be arrested, detained, tortured, isolated, exiled or disposed of arbitrarily". Furthermore, other primary legal materials include Law of the Republic of Indonesia Number 31 of 1997 concerning Military Courts as Procedural Law of Military Courts, Law Number 8 of 1981 concerning the Criminal Procedure Code, and Attachments to Decrees of the Minister of Justice of the Republic of Indonesia Number M. 01. PW. 07.03 of 1982 dated February 4, 1982, concerning Guidelines for the Implementation of the Criminal Procedure Code, which confirms, among other things, the validity of arrests, detentions, termination of investigations, or termination of prosecutions (except for irregularities in cases in the public interest and the Attorney General) (Ibrahim, 2010).

b. Secondary Legal Material
Secondary legal materials are legal materials that explain primary law, such as draft laws, research results, works from legal circles, opinions of legal scholars. In this research on law enforcement, secondary legal materials were obtained from textbooks that discuss law enforcement, the concept of law, the purpose of the law, the judicial system in Indonesia as well as books related to pretrial, as well as the opinions of scholars (military judges), military prosecutors, military law officers, and military convicts) regarding human rights to fulfill the sense of justice of TNI soldiers who are suspects.

c. Tertiary Law Material

Tertiary legal materials are materials that provide instructions or explanations for primary and secondary legal materials, such as dictionaries, encyclopedias, websites, and others.

\section{Legal Materials Collection Techniques}

Data collection techniques carried out by the author are library research and document study (after the literature study is completed, then proceed with document study, but document study is only carried out if the document study is incomplete, incomplete, or deepening). Document studies are carried out in various agencies such as the Directorate of Army Law, the Indonesian Armed Forces Legal Development Agency, Military Police, Military Authority, and other related agencies by applying a willingness to be visited and used as a research site. If the results of the literature study and or document study are also incomplete, confirmation needs to be done so that this research can be widely accepted, which will be carried out on several criminal law experts as academics on the one hand or practitioners on the other.

\section{Legal Material Analysis}

a. Legal materials in the form of primary, secondary, tertiary which have been obtained and compiled through literature study and/or document study and/or identification or clarification studies are reprocessed. Processing of legal materials is carried out by 1) Category or classification, 2) Systematization, 3) Descriptive and critical analysis.

b. Categorization or clarification is carried out on legal materials that have been obtained or collected through literature study or document study or confirmation or clarification studies based on the formulation of the problem to be discussed in this study.

c. After that, the results of the categorization or clarification shall be systematized in such a way based on the pontification of the law and the enforceability of the law. Finally, the legal materials that have been systematized are analyzed descriptively and critically. Descriptive analysis means that the legal materials that have been systematized are described and described in such a way that they are clear and clear.

d. Critical analysis means that the legal materials described above are linked to and tested through the doctrines developed in criminal law in general and military law in particular. 


\author{
Vol: 2, Issue: 11 \\ November $/ 2021$ \\ DOI: http://dx.doi.org/10.47742/ijbssr.v2n11p1 \\ https://ijbssrnet.com/index.php/ijbssr
}

\section{RESULT}

1. Control Mechanisms in the Military Justice System

Before we discuss the concept of criminal pretrial in the military justice system, it is necessary to first know the control mechanism at the law enforcement stage in the criminal justice system in the military justice environment.

\section{Control Mechanism at the Case Investigation Stage}

a. The investigation is a term that is parallel to the meaning of opposing (Dutch) and investigation (English) or tactics or tactics (Malaysia). According to de Pinto as quoted by Andi Hamzah, to investigate (opsporing) means an initial examination by officials for that purpose appointed by law as soon as they in any way hear the news that is simply grounded, that there has been a violation of the law. Furthermore, according to Andi Hamzah, the knowledge and understanding of the investigation need to be stated with certainty and clarity, because it directly offends and limits human rights.

b. Article 1 point 11 of the Law on Military Courts states that what is meant by Investigators of the Armed Forces of the Republic of Indonesia are Ankum, certain Military Police officers, and Public prosecutors, who are given special authority by law to conduct investigations. Meanwhile, the definition of investigation according to article 1 point 16 of the Law on Military Courts states that an investigation is a series of actions by Investigators of the Armed Forces of the Republic of Indonesia in terms of and according to the method regulated by law to seek and collect evidence which with that evidence makes light of the crime. Crime and to find the suspect. An investigation in a military court is different from an investigation in a general court. The legal basis for investigations within the military court is the Military Court Law, especially in Chapter IV which regulates the Military Criminal Procedure Code. Investigation of criminal cases in the general court environment refers to the provisions of the Criminal Procedure Code.

2. Control Mechanisms Against Military Authority

a. The mechanism of control over the composition and powers of the Oditurat is stated in Chapter III Article 47 to Article 68 of Law Number 31 of 1997 concerning Military Courts, stating that the Oditurat exercises state government powers in the field of prosecution and investigation within the armed forces as regulated by law.

b. It also stipulates that judicial technical guidance and supervision for the Judiciary is carried out by the Prosecutor General. Oditurat in the military environment is one and not separate. Organizationally and administratively the Oditurat is under the Commander. The prosecutor in the military court is authorized to carry out investigations into certain cases on the orders of the prosecutor general, to complete the case files by conducting additional examinations before the case is handed over to the court in the general court environment, and to carry out supervision and control in the field of investigation, submission of cases, prosecution, and implementation of decisions within the judiciary general.

c. Control Mechanism at the Case Submission Stage Papera is an officer who by or based on the law has the authority to determine a criminal case committed by a soldier of the Armed Forces of the Republic of Indonesia who are under his command authority submitted to or resolved out of court in a military court or court in a general court environment. Submission of a case is Papera's action to submit a criminal case to a court within the military court or a court within an authorized general court, by demanding that it be examined and tried in matters and according to the method regulated by law. Papera's role in the investigation stage is very dominant because it has the authority to order investigators to carry out investigations.

d. Pretrial Institutions in the Military Justice System in Indonesia from the Perspective of Legal Reform Theory

3. The development of the law at this time was proven by the revision and renewal of several laws and regulations which were deemed no longer relevant to the development and needs of today's society. An orderly society can be achieved if the law is dynamic and follows the development of community needs (Ibrahim, 2010). Legislation which is a legal product must be able to regulate things that are currently needed by the community because the law was formed to ensure the creation of order in society as Mochtar Kusumaatmadja argued that the main and first purpose of the law in order. Therefore, laws and regulations that are no longer relevant are immediately revised and updated to be in line with community developments and current community needs. Mochtar Kusumaatmadja stated that legal reform is not only the entirety of the principles and rules that govern human life in society but also includes the institutions and processes that make these rules come into effect in reality (Mertokusumo 1985). 4. Conception of Pretrial in the Criminal Justice System in Military Courts in Indonesia

a. Pretrial Materials in the Pretrial Concept in the Military Justice System in Indonesia.

To follow the development of national law that can answer the question of protecting the human rights of suspects from detention that is not under legal provisions, it is necessary to regulate the Pretrial Institution as a control institution in the Military Courts system in Indonesia. For this reason, it is necessary to formulate the concept of a Pretrial Institution in the Indonesian Judicial system by updating the Military Criminal Procedure Code contained in the Republic of Indonesia Law Number 31 of 1997 concerning Military Courts. In principle, the philosophy of the pretrial institution that will be built in the military court system is no different from the pretrial institution regulated in the Criminal Procedure Code, namely in the context of providing human rights protection for suspects or defendants as dignified creatures of God, and providing boundaries for 


\title{
International Journal of Business and Social Science Research
}

\author{
Vol: 2, Issue: 11 \\ November $/ 2021$ \\ DOI: http://dx.doi.org/10.47742/ijbssr.v2n11p1 \\ https://ijbssrnet.com/index.php/ijbssr
}

law enforcement officers in carrying out their duties. . Pretrial institutions must reflect that TNI soldiers are also Indonesian citizens whose human rights must be protected and have the same position before the law.

b. Pretrial Procedural Law in the Pretrial Concept in the Military Justice System in Indonesia

The concept of the pretrial procedural law that will be developed is almost the same as that regulated in the Criminal Procedure Code. The Pretrial Session is held at the request of the Suspect or his family or his legal counsel, the Pretrial Trial is an open forum, which is carried out by a Sole Judge to examine Ankum or Papera who has detained a Suspect without fulfilling the provisions of the law so that he must be held accountable for his actions in front of the relevant forum., is it reasonable and based on law. With this testing system through an open trial, it is hoped that the suspect can obtain guarantees for the protection of his human rights in the form of rights and legal remedies to fight the deprivation or restriction of independence carried out arbitrarily by Ankum or Papera.

5. Substance of the Pretrial Concept in the Military Justice System

To enforce pretrial law in the military justice system, namely, to provide legal certainty for the implementation of pretrial, it is necessary to have a separate norm regarding pretrial in Law Number 31 of 1997 (KUHAPMIL), which include the following:

a. Definition. Pretrial is the authority of the High Military Court to examine and decide according to the method regulated in this law, whether or not detention is legal at the request of the suspect or his family or other parties under the authority of the suspect.

b. Pretrial. The High Military Court is authorized to examine and decide, under the provisions stipulated in this law regarding the legality of detention by Ankum or Papera. The Sub-Article concerning the Authority of the High Military Court with a Sole Judge, namely:

i. Those who exercise the authority of the High Military Court as referred to in Article 16 of the Law of the Republic of Indonesia Number 31 of 1997 are Pretrial.

ii. Pretrial is presided over by a single judge appointed by the Head of the High Military Court and assisted by a Registrar.

c. Sub-Article Who Has the Right to File a Pre-Trial Request A request for examination regarding the validity of detention by Ankum or Papera is submitted by the suspect, his family, or his proxies to the Head of the High Military Court by stating the reasons.

d. Sub-Article Provisions of Procedural Law

The pretrial examination procedure for matters as referred to in the Article above is determined as follows:

1. 3 (three) days after receipt of the request, the appointed High Military Judge shall determine the trial day.

2. Examining and deciding whether or not the detention is legal, the Military High Court Judge hears statements from both the suspect or the applicant as well as from the competent authority.

3. The examination is carried out quickly and within seven days the High Military Judge must have rendered his decision.

4. Cases that have begun to be examined by the High Military Court, while the examination of the request to the Pretrial has not been completed, the request is invalid.

5. The decision of the High Military Judge in the pretrial examination must clearly state the basis and reasons.

6. The contents of the decision, in addition to containing the provisions as mentioned above, are also contained if the decision determines that detention is illegal, then Ankum or Papera must immediately release the suspect.

7. The Pretrial Sub-Article cannot be appealed against the pretrial decision in the case as referred to in the above article cannot be appealed.

6. Implications of Pretrial Institutions for Law Enforcement in Military Courts

The discussion on legal reform cannot be separated from the discussion on law enforcement. The problem of law enforcement is the gap between the law normatively (das sollen) and the law sociologically (das Sein) or the gap between the legal behavior of the community that should be and the actual legal behavior of the community. Roscoe pound calls it the difference between "law in the book dan law in action". This difference covers issues including:

a. Does the law in the form of regulations that have been promulgated reveal the patterns of social behavior that existed at that time?

b. Is what the court said the same as what he did.

c. What is the purpose that is expressly desired by regulation in reality? Conceptually, the essence and meaning of law enforcement lie in the activity of harmonizing the relationship of values that are spelled out in solid and embodied rules and attitudes of action as a series of elaboration of the final stage of values, to create, maintain and maintain peaceful social life (Soekanto, 1983).

7. Implications of the Pre-trial Institution for the Position of the Principles of Military Courts in the Military Courts

The Procedural Law in Military Courts as regulated in Law of the Republic of Indonesia Number 31 of 1997 concerning Military Courts is prepared based on a systematic approach by combining various conceptions of the National Criminal Procedure Code, among others, contained in the Republic of Indonesia Law Number 8 of 1981 and the conception of Administrative Procedure Law. The state as stipulated in Law Number 5 of 1986 with various specifics of events originating from the principles and characteristics of the life order of the Armed Forces.

The specifics originating from the principles and characteristics of the life order of the Armed Forces that influence the formation of Military Courts include the Unity of Command Principle, the Principle of the Commander being Responsible for His Subordinates, and the Principle of Military Interest. This principle arises against the background of a situation where a 


\title{
International Journal of Business and Social Science Research
}

\author{
Vol: 2, Issue: 11 \\ November $/ 2021$ \\ DOI: http://dx.doi.org/10.47742/ijbssr.v2n11p1 \\ https://ijbssrnet.com/index.php/ijbssr
}

commander who is carrying out an operational task does not know that his subordinates are being detained by the Military Police because they are suspected of committing a crime. Therefore, considering that the Commander needs his subordinates to carry out operational tasks, the principle of Unity of Command is needed, the principle of the Commander being Responsible for His Subordinates, and the principle of Military Interest (General Elucidation of Law of the Republic of Indonesia Number 31 of 1997, General Secretariat of TNI Headquarters, Jakarta, 1999).

Pretrial provisions are not regulated in Indonesian Law Number 31 of 1997, it should be understood that there is an assumption that the Pretrial lawsuit is an attitude of correction and distrust of superiors or commanders either as Ankum or Papera, so that if this is adopted in the Military Procedural Law will bring consequences for subordinates dealing with superiors who can shake loyalty, hierarchy and military discipline as well as the authority of the commander. In the life of the military community today, the debate, the pro-contra stance among the military itself is not non-existent. In general, the views that are against or who disagree with the existence of Pretrial look at the aspects of the military hierarchy and the importance of the chain of command and the unity of command, so that Pretrial means that it allows a subordinate to assess, analyze and even correct this seen as a denial of the principle of unity and the chain of command that prevails in the military hierarchy. Those who agree, the Pretrial will look at the protection aspect of the rights of the military/TNI soldiers whose estuary is the aspect of justice and human rights. That even though in the life of a military society there is a need for genuine obedience and obedience from a subordinate to his superior/commander in receiving or carrying out orders or decisions, one's rights must still be protected by Human Rights.

\section{IMPLICATIONS}

Implications of Pretrial in the criminal justice system within the Military Court on the position of Ankum and Papera. The position of Ankum and Papera in the concept of a pretrial institution that will be built in the Military Justice System in Indonesia needs to be a concern because the existence of an Ankuman institution and a paperwork institution is a hallmark or specialty of a Military Court.

Ankum and Papera are officials appointed by law to carry out their authority. Ankum has the authority to impose disciplinary punishments carried out by TNI soldiers under his command authority, while Papera has the authority to decide whether criminal cases committed by soldiers under his command should be submitted to the competent court, close cases for legal or public/military interests or resolve cases. through disciplinary punishment, thus giving consequences to Papera having the authority to order investigators to carry out investigations, receive reports on the conduct of investigations and even order coercive measures to be carried out (Technical Instructions Number Kep/428/V/2016 dated 23 May 2016).

In another position, Ankum is also an investigator together with the Military Police and Military Prosecutor as regulated in Article 69 paragraph (1) of the Law of the Republic of Indonesia Number 31 of 1997. As described in the previous discussion, Ankum has the authority to:
1. Conducting investigations on subordinate Soldiers who are under the authority of their command, the implementation of which is carried out by Military Police investigators and Military prosecutors.

2. Receive reports on the conduct of investigations from Military Police investigators or Military prosecutors.

3. Receive case files resulting from investigations from military police investigators or military prosecutors.

4. Detaining the suspect members of his subordinates who are under the authority of his command.

In Article 78 of the Law of the Republic of Indonesia Number 31 of 1997, Ankum and Papera are given the authority to detain suspected members of their subordinates who are under the authority of their command, which authority is for a maximum of 20 (twenty) days, and if necessary for examination, can be extended. by the competent Papera by his decision for every 30 (thirty) days and a maximum of 180 (one hundred and eighty) days.

\section{CONCLUSION}

Based on the problems and results of the above discussion, the writing of this journal can be summarized as follows:

1. Pretrial Institutions in the Military Justice System in Indonesia need to have a place in the Military Courts system in Indonesia regarding the legality of detention by Ankum/Papera for the following reasons:

a. Aligning with the legal goals that aspire to, namely Justice (Gerechtigkeit), Legal Certainty (Rechssicsherheit), and Benefit (Zweckmabigkeit) for suspected TNI soldiers in defending their human rights as citizens so that RI Law Number 31 of 1997 concerning Military Courts can follow developments the military community on the issue of detention by its Commander.

b. The principle of the Unity of Command and the principle of the commander is responsible for his subordinates must be carried out properly and correctly so that the commander knows whether his subordinates are detained or not, when they are detained or for how long, and where they are being held, or the commander cares and is responsible for his subordinates who are undergoing legal proceedings. The principle is that the Pretrial Institution that will be built in the Indonesian Judicial System does not reduce the loyalty and discipline of TNI soldiers and the Commander's Authority.

c. The Pretrial Institution protects the Commander (Ankum/Papera) so as not to violate human rights and protect the interests of the human rights of TNI soldiers who are being investigated in the legal process.

d. The Pretrial Institution reflects that TNI soldiers are also Indonesian citizens whose human rights must be protected and have the same position before the law.

e. The Pretrial Institution is a breakthrough in reforming the Military Criminal Procedure Code as an effort to review and reorient (reorient and deconstruct) the Military Criminal Procedure Code under the development of the military community as part of the development of 


\title{
International Journal of Business and Social Science Research
}

\author{
Vol: 2, Issue: 11 \\ November $/ 2021$ \\ DOI: http://dx.doi.org/10.47742/ijbssr.v2n11p1 \\ https://ijbssrnet.com/index.php/ijbssr
}

national law so that the Military Court Law is under its spirit in upholding justice, truth, order and legal certainty. 2. The conception of Pretrial in the Military Justice System in Indonesia is generally the same as that of Pretrial Institutions regulated by the Criminal Procedure Code, namely:

a. Establish the structure, substance, and culture of the Pretrial where the suspect can file charges against procedural errors and or the absence or delay of the Detention Order. The structure, substance, and legal culture are expected to fulfill the rights of suspects, in this case, the military/TNI soldiers, to obtain justice as well as their rights and dignity as citizens who have equal standing before the law.

b. Pretrial requirements conceptualized in the Military Justice System in Indonesia are not the same as in the Criminal Procedure Code by including all pretrial requirements such as legal or illegal arrest, detention, termination of investigation and prosecution, as well as compensation and/or rehabilitation for a person whose criminal case is terminated at the level of investigation or prosecution. This is adjusted to the development and demands of the Military community, where the conception of Pretrial in the Military Justice System only requires the legality of detention because the problem of detention is often found in law enforcement practices in the Military Justice System in Indonesia where Ankum or Papera often detain suspects arbitrarily such as detaining without or delaying a warrant which constitutes a violation of human rights.

c. The pretrial implementation is carried out by the High Military Court in the jurisdiction of the detention area and considering that Ankum or Papera who issued the Detention Order is of the rank of Intermediate Officer (Major and above) so that at least the Judge who examines and hears the trial is of the same rank as the rank being tried. The trial is presided over by a Sole Judge appointed by the Chief Military High Court and assisted by a Substitute Registrar.

d. The person who has the right to file a pretrial (in terms of legal or illegal detention) is the suspect, his family, or his legal representative.

e. Renewal of law regulating Pretrial Institutions in Military Criminal Procedure Code in Indonesia is carried out by reorienting (reorienting and deconstructing) Military Judicial Procedural Law into a concept by adding Article Definition of Pretrial in Chapter I General Provisions and adding a special Chapter on Pretrial which includes pretrial requirements. , the authority of the High Military Court with a single Judge, who has the right to file a Pretrial request, the provisions of the procedural law, and the Pretrial cannot be appealed.

3. The existence of Pretrial in the Military Justice System will have an impact and have implications for:

a. The realization of the strengthening of the legal structure (Ankum and Papera) due to the return of the control function in law enforcement so that Ankum and Papera avoid human rights violations.

b. The realization of aspects of legal protection for military/TNI soldiers who become suspects because there is control over the arbitrariness or discrimination of Ankum/Papera in detention against him.

c. The realization of good and more measurable personnel development by Ankum and Papera as unit commanders. d. The creation of a new climate or culture for the implementation of the law enforcement system within the Military Courts that is more harmonious and upholds the values of Human Rights as the hallmark of a state of law.

\section{REFERENCES}

Ahmad Mujahidin, (2007). One Roof Court in Indonesia, PT Refika Aditama, Bandung.

Andi Anas Chaerul M., (2021). http;//andianaschaerul.blogspot.nl/2013/03/praperadilan-lahir-dari-insperasi.html accessed on 7 August 2021.

Article 1 paragraph (9) of Law Number 31 of (1997) concerning Military Courts.

DY. Witanto, (2019). Pretrial Procedural Law in Theory and Practice, Maji Cipta Karya, Jakarta.

General Elucidation of Law of the Republic of Indonesia Number 31 of 1997, General Secretariat of TNI Headquarters, Jakarta, 1999.

In the Technical Manual Number Kep/428/V/2016 dated May 23, (2016). Concerning the Authority of Papera and Ankum within the Indonesian Army.

Johnny Ibrahim, (2010). Normative Law Research Theory and Methodology, Bayumedia Publishing, Malang,

Kaka Alvian Nasution, (1945) Constitution and Amendments plus Profile of the President and Vice President 2014-2019,

First Printing, 2014.

Luhut M.P. Pangaribuan, (2008). Renewal of the Criminal Procedure Code: Official Letters in Court by an Advocate,

Djambatan, Jakarta.

Mochtar Kusumaatmadja (2002) Legal Concepts in Development-Function and Development of Law in National Development, Center for the Study of Archipelago Insights, Bandung Alumni.

Soedikno Mertokusumo, (1985). Knowing the Law is an Introduction, Liberty, Yogyakarta. 


\section{International Journal of Business and Social Science Research}

Vol: 2, Issue: 11

November/2021

DOI: http://dx.doi.org/10.47742/ijbssr.v2n11p1

https://ijbssrnet.com/index.php/ijbssr

Soerjono Soekanto (1983). Factors Affecting Law Enforcement, Rajawali, Jakarta.

Soetandyo Wignjosoebroto (1995). Sebuah Pengantar ke Arah Perbincangan tentang Pembinaan Penelitian Hukum Dalam PJP II, Makalah, Disampaikan dalam Seminar Akbar 50 Tahun Kemerdekaan, BPHN, Departemen Kehakiman, Jakarta.

Stiawan Widagdo (2012). Kamus Hukum, Prestasi Pustaka, Jakarta.

Sudikno Mertokusumo. (2005). Mengenal Hukum Suatu Pengantar, Liberty, Yogyakarta. 